In Miss Bowley's practical work as a psychologist she has made considerable use of Raven's controlled projection test, in which the interview with the child is systematized without being made inhuman. While the child is drawing he is asked to help tell a story, and in this way he expresses his conscious joys, fears, hopes, imaginings, and his remembered dreams. Those in charge of a group of children who read this book may wonder at the relatively superficial picture that tests give, and the author might have included an explanation that psychologists do tests for the purposes of research and teaching and the presentation of materiai, and that these things have value as well as the actual care of the children. The glossary needs to be rewritten. For example : "Guilt feeling-a technical psychological term indicating a sense of shame which is largely repressed." Either guilt feeling means something quite evident, or else it means repressed guilt, or guilt in respect of repressed ideas or feelings. The word shame simply waters the concept down without adding anything useful. Again: "Psychiatric. the art of healing the mind," and "Prophylactic-preventative." If preventative (or preferably preventive) is clearer, why not use it in the text? "Oral-relating to the mouth, anal-relating to the anus." This explanation is quite useless unless the whole theory of erogenous zones is presented. And so on. Such , criticisms do not, however, detract from the value of this and all books written to gather together and present the results of a piece of field work

\section{W. WinNiCOTt.}

\section{DISEASES OF THE BREAST}

Diseases of the Breast. By Sir Crisp English, K.C.M.G..
F.R.C.S. (Pp. 128. 8s. 6d.) London: J and A. Churchill, Ltd. 1948.

This is a plain straightforward account of most of the conditions affecting the breast. It is of course impossible within the compass of 128 pages to give anything like a full account of diseases of the breast, but the author has wisely put due emphasis on the more serious lesions Nevertheless he has to a certain extent been handicapped by two limitations-the absence of illustrations and the failure to draw more freely upon his own great experience. A good illustration may teach more surely and more quickly than a long description, particularly when discussing affections of the breast. A few well-chosen pictures would greatly enhance the book's usefulness. The author gives many references, but we could spare some of them for an account from his ripe experience of personal cases or statistical results. However, it will no doubt be possible to remedy both these defects in a future edition.

\section{ZACHARY COPE.}

\section{YOUNG WOMEN}

The Childbearing Years. By C. Scott Russell, M.A., F.R.C.S.Ed. M.R.C.O.G. Drawings by Miss M. McLarty. (Pp. 88; illusirated. 7s. 6d.) Oxford: Blackwell Scientific Medical Publications. 1947

In the words of the preface, the theme of this book is "the process by which women conceive and bear children; its variations and some of the harmonies and disharmonies linked to this process." It was written because the author "felt that young ,women needed a book about themselves." There are chapters on anatomy, menstruation, normal pregnancy and childbirth, disordered function in pregnancy and labour, sterility, abortion, and disorders in middle age. A mere enumeration of the subjects discussed conveys, however, little idea of the quality and interest of the contents. The author has an enviable gift of readable exposition and omits to consider none of the necessary facts, illustrating them from personal experiences and with accounts from medical history of the Dionne quintuplets, anaesthesia, puerperal fever, the first ovariotomy by the father of abdominal surgery, and others that make the whole into an interesting story. Seldom indeed has the reviewer read a book of its kind that can be recommended more unreservedly. Every young woman should read it. To alter slightly the modest concluding sentence of the preface, while the book is primarily for those between 17 and 30, parents, teachers, and others will find it both interesting and of value.

\section{F. J. BROWNE}

\section{BOOKS RECEIVED}

[Review is not precluded by notice here of books recently received]

Breast Feeding. By F. Charlotte Naish, B.A., M.B., B.Ch. (Pp. 151. 10s. 6d.) London: Geoffrey Cumberlege. 1948.

Accorded the B.M.A. Sir Charles Hastings Clinical Essay Prize

Major Endocrine Disorders. By S. Leonard Simpson, M.A., M.D., F.R.C.P. 2nd ed. (Pp. 552. 42s.) London: Oxford University Press. 1948.

This edition has been largely rewritten and references are now included.

Anatomy. By A. D. Le Vay, M.S., F.R.C.S. (Pp. 299. 4s. 6d.) London: English Universities Press. 1948.

A simple introduction to human anatomy

L'Exploration Fonctionnelle des Reins By Jules Cottet. (Pp. 207. 400 francs.) Paris: L'Expansion Scientifique Française. 1948. On the estimation of renal function in clinical practice.

Modern Trends in Diagnostic Radiology. Edited by J. W McLaren, M.A., M.R.C.S., L.R.C.P., D.M.R.E. (Pp. 464.60 s.) London: Butterworth. 1948

Chapters by various authorities on modern radiology.

Médectne de L'Aviation. By J. Malmejac. (Pp. 333. 1,200 francs.) Paris: Masson. 1948.

The physiological and medical aspects of flying, with extensive bibliography:

Trubs'King By Mary King. (Pp. 355. 18s.) London: Allen. 1948.

A biography

The Sulfonamides and Allied Compounds. By Elmore $H$ Northey. Ph.D. (Pp 660 75s.) London: Chapman and Hall 1948.

A monograph on the chemistry and pharmacology of the sulphonamides.

Cardiovascular Diseases. By David Scherf, M.D., F.A.C.P., and Linn J. Boyd, M.D., F.A.C.P. 2nd ed. (Pp. 743. 63s.) London: Heinemann 1948

A manual of diagnosis and treatment, with references

A Manuat of Practical Obstetrics. By O'Donel Browne, M.B. M.A.O., M.A., Litt.D., F.R.C.P.I., F.R.C.O.G. 2nd ed. (Pp. 267 35s.) London: Simpkin, Marshall. 1948.

Intended for the student and general practitioner

Curative Education. By Isabel Newitt. (Pp. 83. 2s. 6d.) London: Anthroposophical Publishing Co. 1942.

The education of backward and abnormal children based on the teachings of Rudolf Steiner.

A Direct Entry to Organic Chemistry By John Read, F.R.S. Ph.D., M.A., Sc.D. (Pp. 268. 4s. 6d.) London: Methuen. 1948 An account for the intelligent layman.

Recent Advances in Cardiology. By Terence East, M.A., D.M. F.R.C.P., and Curtis Bain, M.C., D.M., F.R.C.P. 4th ed. (Pp. 545 24s.) London: Churchill. 1948

The book has been rewritten to incorporate recent knowledge

One Truth One People. By His Holiness Rajji Maharaj. (Pp 104. Rs. 3.) Jodhpur: Chain Puri. 1945.

A spiritual approach to world conflicts.

La Isla Iluminada. By J. A. Osorio Lizarazo (Pp. 205. No price.) Santiago: Editorial el Diario 1947

An account of the "enlightened isle," San Domingo.

Neurology of the Ocular Muscles. By David G. Cogan, M.D. (Pp. 214. 25s.) Oxford: Blackwell. 1948.

Relates clinical signs to anatomy and physiology.

Lecture Notes on Pharmacology, By J. H. Burn, M.D., F.R.S (Pp. 128. 6s.) Oxford: Blackwell. 1948.

Intended for medical students. 